\title{
一般演題 29
}

\section{毛細管型人工腎臓における血液閉塞について}

\author{
吉島 博* 山平伸光* 菊地聖司* \\ 阿等鉄三* 太田和夫*
}

\section{目 的}

Hollow, Fiber, Artifital, Kidney. (以下 HFK と略す）注，比較的小型で，血液充提星が少な

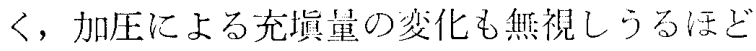
でありままたりークダ少ないなどの利点も范げ られ，血液透析に広く使わ扎る5うになってき ている.

HFK の情造は，生体の未梢血管期遗に類似 して拀り，血液透析装犆として基本的には，一 つの理想的な形を示したといえよう。

しかし現在の使用されている HFK は，ホル マリン液に浸積した Wet type であるため, そ

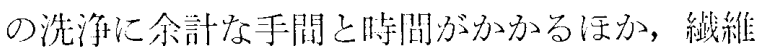
内に未汀る凝血形成傾向のため，透析能率が低 ドするばかりでなく，残血星が多くなるという 众点がある。

今回，わ狄わ狆は凝血による能摔低下の䦌题 解汱の手掛りをえようとして笑験研究を行なっ たので報告する。

\section{方法}

笑験 1 胣品床使用の前後における HFK の变 化 Cordis. Dow. M-4 空用い，血流量は 200 $\mathrm{ml} / \mathrm{min}$ とし, 透析液流量は $500 \mathrm{ml} / \mathrm{min}$ で 5 時間透析を行ない，以下の点について検討した。

なお， 一パリン使用量は 9,000 単位である.

(1) 透析開始 10 分後掞よび, 終了直前に䘏 液を採取しクリアランスを測定し，HFK 束中 の凝血形成による透析效率への影響定しらべ た。

(2) 凝血形成の状態をしらべるため，1回 1 回の透析終了後に，HFK の向液キャップをは オ゙し余分な血液をふきとり，フォイぐの断面の

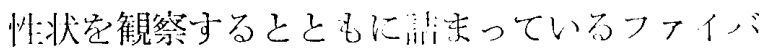

*東京女子医科大学人工腎臟センター

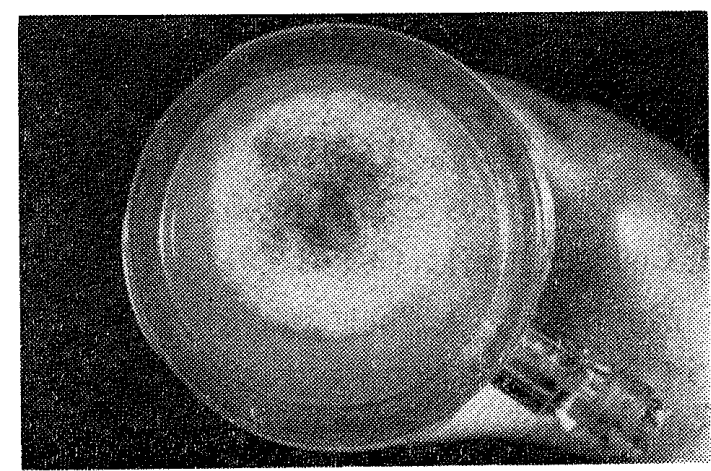

図 1

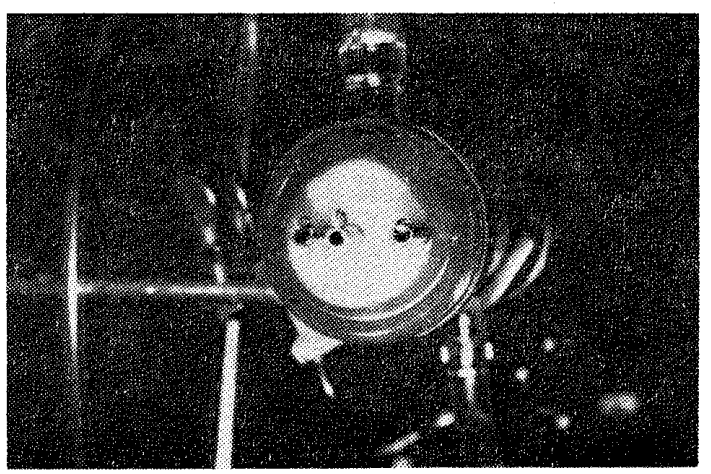

図 2

と、部まっていないフォイバとを識別するため, 色素学注入して検討を行なった。

実験 $2 \mathrm{HFK}$ 血液出口側のキャップを取り はずし, Hollow, Fiber 束の中心部, 中間部, 周辺部に同じ大きさの金属パイプをさし込み， それぞれの部位から別々に，血液代用液を採取 できるようなモデル它作製した。1 本のパイプ

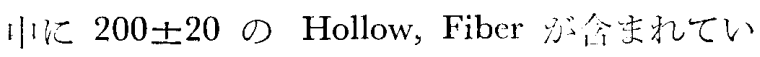
る.

この HFK を図 3 のように, 模凝回路中に セット乙透析液としては水道水学朋いて, Single Pass 方式とし，II!液代用液㧈上び唀析液の

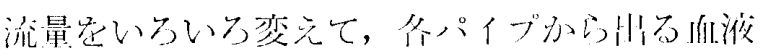

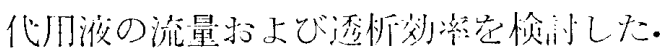




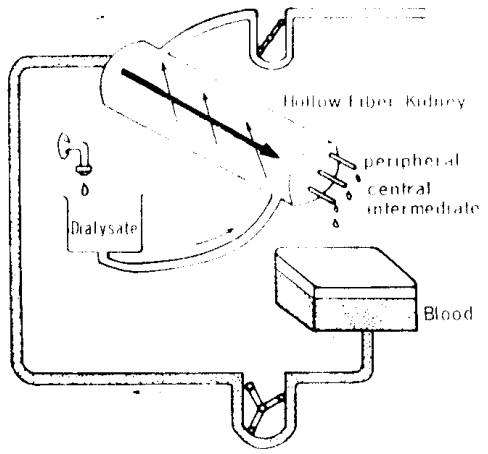

图 3

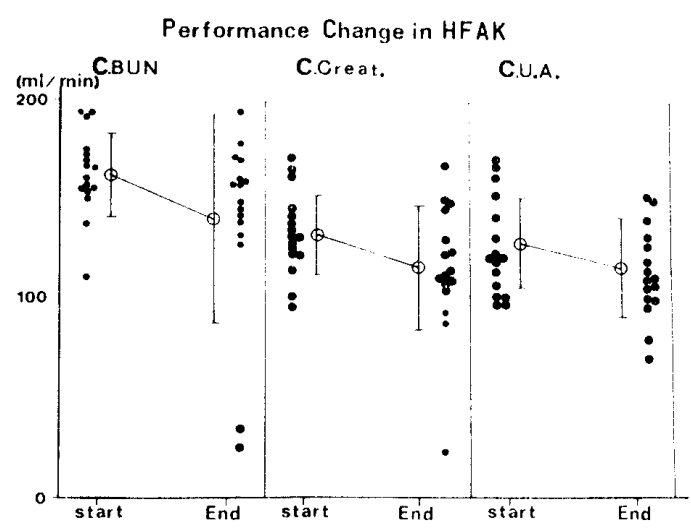

図 4

\section{成績}

使用後の HFK の血液キャップをはずして観 察すると，血栓により閉塞している Fiber を確 認することができた，閉塞している Fiber は， 主に中心部にあり周辺に閉塞があるものでも必 ず中心部の閉塞を伴なっていた。

なお，凝血形成の透析効果におよぼす影響を， 16 例につき透析前後で検討したところ，尿素， クレアチニン，尿酸のクリアランス注，それぞ れ 14\%，14\%，10\% の低下を示した。

ここで注意しなければならないのは，HFK の中には，80\%にによぶ效率低下をきたした ものがあるという事実である。この点に関し て，In，Vitro. 回路でくわしく追求した結果， 図 5 のように血流の分有は，中心部に比べて届 辺部の方が多く，この傾向政全体の血流昰の多 いほど明らかになった・極端な場命にい心部の 血流は，中間部，周辺部の 1/3〜1/4 である。

また尿素クリフランスも中心部は図 6 に示す ごとく極めて低く，ときには周辺部の 1/4 1/5 のクリアランスしか得られなかった。
Blood Distribution of HFAK

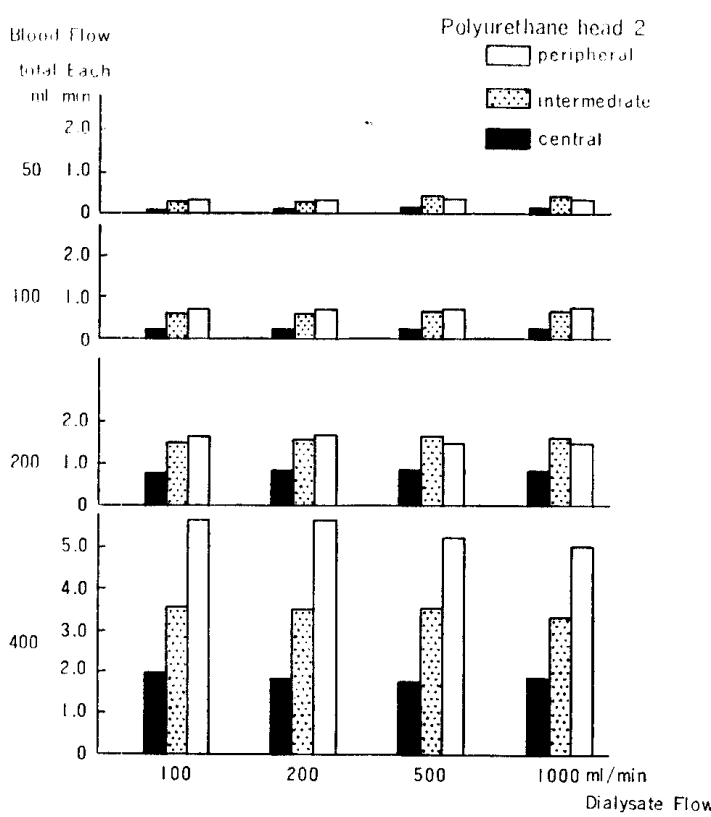

図 5

\section{Urea Clearance of HFAK}

Polyurethane head.2

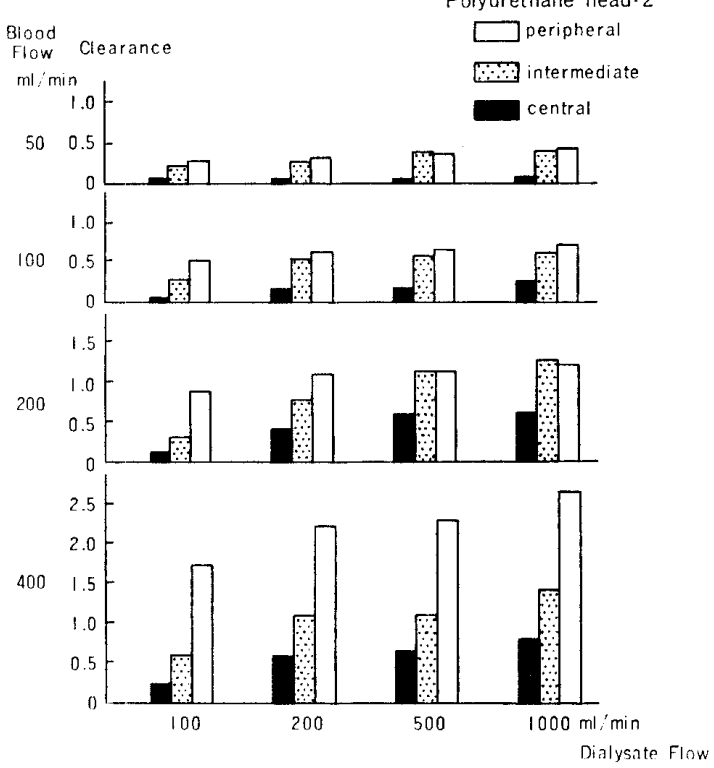

図 6

結論

これらの実験成績から Cordis, Dow HFK M -4の血液透析中に扮汀るフォイバ内凝血形成 小よび透析能率低下の主な原因は，この透析装 消がなんらかの理由，おそらく注作成上の過程 でフォイバ束の中心部が周辺部に比べて血流星 が少なくなっているためと考光られる。 
付 議

宗丁医科丁栄(怢) 井上政 昭

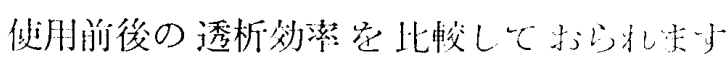

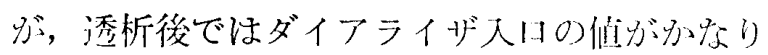
低くなっているので，クリナランス在刘管には 比較できないのではないでしょうか。
回 答

來京从子医大 吉 島 博

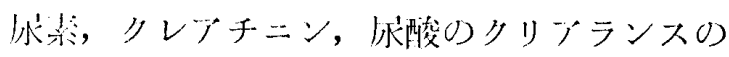
結果以，艺犳艺狆 14\%，14\%，10\% という值

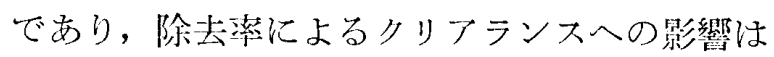
考光られませえが，どれぐらいの影響があるか 検討をかさ称て行きたい上思う。 